\title{
Bibliometric analysis of Severe Acute Respiratory Syndrome-related research in the beginning stage
}

\author{
WEN-TA ChIU, ${ }^{\text {a }}$ Jing-SHAN HUANG, ${ }^{b}$ YUH-SHAN HO ${ }^{a, c}$ \\ a Taipei Medical University - Wan-Fang Hospital, Taipei (Taiwan) \\ b Cathay General Hospital, Taipei (Taiwan) \\ c School of Public Health, Taipei Medical University, Taipei (Taiwan)
}

\begin{abstract}
Severe Acute Respiratory Syndrome (SARS) has become the major of health issues since its outbreak early 2003. No analyses by bibliometric technique that have examined this topic exist in the literature. The objective of this study is to conduct a bibliometric analysis of all SARS-related publications in Science Citation Index (SCI) in the early stage. A systematic search was performed using the SCI for publications since SARS outbreak early 2003. Selected documents included 'severe acute respiratory syndrome' or 'SARS' as a part of its title, abstract, or keyword from the beginning stage of SARS outbreak, March till July 8, 2003. Analysis parameters included authorship, patterns of international collaboration, journals, language, document type, research institutional address, times cited, and reprint address. Citation analysis was mainly based on impact factor as defined by Journal Citation Reports (JCR) issued in 2002 and on the actual citation impact (ACI), which has been used to assess the impact relative to the whole field and has been defined as the ratio between individual citation per publication value and the total citation per publication value. Thirty-two percent of total share was published as news features, $25 \%$ as editorial materials, $22 \%$ as articles, $13 \%$ as letters, and the remaining being biographic items, corrections, meeting abstracts, and reprints. The US dominated the production by $30 \%$ of the total share followed closely by Hong Kong with $24 \%$. Sixty-three percent of publication was published by the mainstream countries. The SARS publication pattern in the past few months suggests immediate citation, low collaboration rate, and English and mainstream country domination in production. We observed no associations of research indexes with the number of cases.
\end{abstract}

\section{Introduction}

Infectious diseases have always been a threat to humans, especially when social conditions were continuously changing. Well-known epidemics such as the bubonic plague, AIDS, the Ebola virus in the 1980s, the influenza pandemic of 1918, and presently, the Severe Acute Respiratory Syndrome (SARS) has seriously affected us. ${ }^{1}$ SARS was first identified in February 2003 by an Italian expert, Carlo Urbani and his early work to detect SARS has heightened the global surveillance level and made many

Received March 30, 2004

Address for correspondence:

YUH-SHAN HO

Bibliometric Centre, Taipei Medical University - Wan-Fang Hospital

111 Hsing-Long Road Sec. 3, Taipei 116, Taiwan

E-mail:ysho@tmu.edu.tw

0138-9130/2004/US \$20.00

Copyright (C) 2004 Akadémiai Kiadó, Budapest

All rights reserved 
new cases identified. ${ }^{2}$ SARS broke out rapidly and seriously affected life in Hong Kong, Singapore, Toronto, Taiwan, and various regions of China since early March 2003. From November 1st 2002 to June 6th 2003, there were 8,404 SARS cases with 779 deaths and with 5,937 being recovered. ${ }^{3}$ The technique to sequence SARS virus was completed in mid April 2003 to make future development of drugs and vaccines possible.

The defensive move the human will take against this disease can only be established among scientists with sufficient communications. The most common mean is through publication. ${ }^{4}$ Garfield in 1970 also observed that a recent research focus can be reflected on its publication output. ${ }^{5}$ Hence, a dramatic increase of SARS-related publications would be expected shortly after the outbreak. This study was intended to analyze significant SARS publication patterns, especially in international collaboration and authors' country of origin in the beginning stage of SARS outbreak.

\section{Materials and methods}

Publications used in this analysis were extracted from the Science Citation Index (SCI) established by the Institute of Scientific Information (ISI), in Philadelphia, the United States. Selected documents included 'severe acute respiratory syndrome' or 'SARS' as a part of its title, abstract, or keyword from March till the update of July 8, 2003. Then, we checked the search result to make sure that all entries were related to the SARS topic. Analysis parameters include authorship, patterns of international collaboration, journals, language, document type, research institutional address, times cited, and reprint address. Citation analysis was partly based on Journal Impact Factors, as defined by Journal Citation Report (JCR) for the journals actually published the SARS articles (Table 1) partly on the number of citations received per publication during the period studied in 2003, and relative to the average citation impact of the SARS publications covering the same period (Table 2). The average citation impact, corresponding to a kind of Immediacy Index for SARS, 2003, was 0.735 citations per published article with research institutional address (97 cit./132 publ.), January-July, 2003.

\section{Results and discussion}

Six papers were published in March, 45 in April, 132 in May, 68 in June and 2 in July as of July 8th. Total production was 256 papers by 38 countries with $48 \%$ being absent in recorded address. Thirty-two percent of total share was published as news features, $25 \%$ as editorial materials, $22 \%$ as articles, $13 \%$ as letters, and the remaining being biographic items, corrections, meeting abstracts, and reprints. 
W. T. CHIU et al.: SARS-related research

Table 1. Publication, impact factor, and country distribution of journals

\begin{tabular}{|c|c|c|c|c|}
\hline Journal & IF & $\begin{array}{c}\text { Journal } \\
\text { Country }\end{array}$ & $\mathrm{P}$ & $\% \mathrm{P}$ \\
\hline Lancet Infectious Diseases & - & - & 5 & 1.95 \\
\hline Lancet Oncology & - & - & 1 & 0.391 \\
\hline New England Journal of Medicine & 31.736 & USA & 15 & 5.86 \\
\hline Nature & 30.432 & UK & 13 & 5.08 \\
\hline Nature Medicine & 28.74 & USA & 2 & 0.781 \\
\hline Science & 26.682 & USA & 18 & 7.03 \\
\hline JAMA-Journal of the American Medical Association & 16.586 & USA & 21 & 8.20 \\
\hline Lancet & 15.397 & UK & 43 & 16.8 \\
\hline Journal of Clinical Investigation & 14.051 & USA & 1 & 0.391 \\
\hline Gastroenterology & 13.44 & USA & 1 & 0.391 \\
\hline British Medical Journal & 7.585 & UK & 30 & 11.7 \\
\hline Current Biology & 7.007 & USA & 1 & 0.391 \\
\hline Faseb Journal & 7.252 & USA & 1 & 0.391 \\
\hline Molecular Therapy & 6.275 & USA & 1 & 0.391 \\
\hline Clinical Chemistry & 4.788 & USA & 2 & 0.781 \\
\hline Emerging Infectious Diseases & 4.757 & USA & 2 & 0.781 \\
\hline Journal of Nuclear Medicine & 4.587 & USA & 1 & 0.391 \\
\hline Journal of Medicinal Chemistry & 4.566 & USA & 1 & 0.391 \\
\hline Clinical Infectious Diseases & 4.75 & USA & 4 & 1.56 \\
\hline Journal of Urology & 3.03 & USA & 1 & 0.391 \\
\hline European Respiratory Journal & 2.931 & Denmark & 1 & 0.391 \\
\hline Canadian Medical Association Journal & 3.22 & Canada & 17 & 6.64 \\
\hline Radiation Research & 2.768 & USA & 2 & 0.781 \\
\hline Journal of Applied Physiology & 2.72 & USA & 1 & 0.391 \\
\hline Bulletin of the World Health Organization & 2.694 & Switzerland & 3 & 1.17 \\
\hline Scientific American & 2.456 & USA & 1 & 0.391 \\
\hline British Journal of Anaesthesia & 2.098 & UK & 1 & 0.391 \\
\hline Bioorganic \& Medicinal Chemistry Letters & 2.051 & UK & 2 & 0.781 \\
\hline Bioorganic \& Medicinal Chemistry & 2.043 & USA & 1 & 0.391 \\
\hline American Journal of Roentgenology & 2.424 & USA & 2 & 0.781 \\
\hline Journal of Biogeography & 1.788 & UK & 1 & 0.391 \\
\hline International Journal of Tuberculosis and Lung Disease & 1.888 & France & 1 & 0.391 \\
\hline Medical Journal of Australia & 1.673 & Australia & 4 & 1.56 \\
\hline Marine Biology & 1.672 & Germany & 1 & 0.391 \\
\hline
\end{tabular}


W. T. CHIU et al.: SARS-related research

Table 1. continued

\begin{tabular}{|c|c|c|c|c|}
\hline Journal & IF & $\begin{array}{c}\text { Journal } \\
\text { Country }\end{array}$ & $\mathrm{P}$ & $\% \mathrm{P}$ \\
\hline Journal of the American Statistical Association & 1.669 & USA & 1 & 0.391 \\
\hline British Journal of General Practice & 1.593 & UK & 3 & 1.17 \\
\hline Journal of the American Veterinary Medical Association & 1.25 & USA & 1 & 0.391 \\
\hline Clinical Radiology & 1.048 & UK & 1 & 0.391 \\
\hline Medicina Clinica & 0.854 & Spain & 2 & 0.781 \\
\hline Cleveland Clinic Journal of Medicine & 0.722 & USA & 1 & 0.391 \\
\hline Journal of Crustacean Biology & 0.724 & USA & 1 & 0.391 \\
\hline Journal of Small Animal Practice & 0.704 & UK & 1 & 0.391 \\
\hline International Journal of Surgical Pathology & 0.663 & USA & 1 & 0.391 \\
\hline Deutsche Medizinische Wochenschrift & 0.651 & Germany & 3 & 1.17 \\
\hline Journal of Biosciences & 0.606 & India & 1 & 0.391 \\
\hline Chinese Science Bulletin & 0.57 & Peoples R China & 1 & 0.391 \\
\hline Chemical \& Engineering News & 0.465 & USA & 6 & 2.34 \\
\hline Chemistry \& Industry & 0.461 & UK & 3 & 1.17 \\
\hline New Scientist & 0.277 & USA & 6 & 2.34 \\
\hline Organisms Diversity \& Evolution & 0.45 & Germany & 1 & 0.391 \\
\hline Infections in Medicine & 0.298 & USA & 1 & 0.391 \\
\hline Physician and Sportsmedicine & 0.492 & USA & 1 & 0.391 \\
\hline Presse Medicale & 0.395 & France & 1 & 0.391 \\
\hline Scientist & 0.365 & USA & 1 & 0.391 \\
\hline Saudi Medical Journal & 0.301 & Saudi Arabia & 1 & 0.391 \\
\hline Laboratory Medicine & 0.259 & USA & 1 & 0.391 \\
\hline American Journal of Nursing & 0.242 & USA & 3 & 1.17 \\
\hline Geriatric Nursing & 0.168 & USA & 1 & 0.391 \\
\hline Natural History & 0.157 & USA & 1 & 0.391 \\
\hline Genetic Engineering News & 0.114 & USA & 3 & 1.17 \\
\hline Aviation Week \& Space Technology & 0.023 & USA & 4 & 1.56 \\
\hline Professional Engineering & 0.04 & UK & 1 & 0.391 \\
\hline Veterinary Economics & 0.025 & USA & 1 & 0.391 \\
\hline E\&MJ-Engineering and Mining Journal & 0.011 & USA & 1 & 0.391 \\
\hline
\end{tabular}

IF: Impact factor, P: Publication, \%P: Percentage of publication 
W. T. CHIU et al.: SARS-related research

Table 2. Publication, citation, and case number distribution among origin of countries

\begin{tabular}{|c|c|c|c|c|c|c|c|}
\hline Country & Cases & $\%$ Cases & $\mathrm{P}$ & $\% \mathrm{P}$ & $\mathrm{C}$ & $\% \mathrm{C}$ & ACI \\
\hline USA & 68 & 0.809 & 39 & 29.5 & 12 & 12.4 & 0.419 \\
\hline Hong Kong & 1750 & 20.8 & 32 & 24.2 & 64 & 66.0 & 2.72 \\
\hline Canada & 219 & 2.61 & 22 & 16.7 & 18 & 18.6 & 1.11 \\
\hline UK & 4 & 0.0476 & 15 & 11.4 & 5 & 5.15 & 0.454 \\
\hline Singapore & 206 & 2.45 & 12 & 9.09 & 11 & 11.3 & 1.25 \\
\hline Germany & 10 & 0.119 & 11 & 8.33 & 9 & 9.28 & 1.11 \\
\hline Taiwan & 676 & 8.04 & 6 & 4.55 & 8 & 8.25 & 1.81 \\
\hline Switzerland & 1 & 0.0119 & 5 & 3.79 & 0 & 0 & 0 \\
\hline Spain & 1 & 0.0119 & 4 & 3.03 & 0 & 0 & 0 \\
\hline Netherlands & 0 & 0 & 3 & 2.27 & 10 & 10.3 & 4.54 \\
\hline Thailand & 8 & 0.0952 & 3 & 2.27 & 7 & 7.22 & 3.18 \\
\hline Vietnam & 63 & 0.750 & 3 & 2.27 & 7 & 7.22 & 3.18 \\
\hline France & 7 & 0.0833 & 2 & 1.52 & 5 & 5.15 & 3.40 \\
\hline India & 3 & 0.0357 & 2 & 1.52 & 0 & 0 & 0 \\
\hline Australia & 5 & 0.0595 & 2 & 1.52 & 0 & 0 & 0 \\
\hline Belgium & 0 & 0 & 1 & 0.758 & 0 & 0 & 0 \\
\hline Mexico & 0 & 0 & 1 & 0.758 & 0 & 0 & 0 \\
\hline Norway & 0 & 0 & 1 & 0.758 & 0 & 0 & 0 \\
\hline Saudi Arabia & 0 & 0 & 1 & 0.758 & 0 & 0 & 0 \\
\hline Senegal & 0 & 0 & 1 & 0.758 & 0 & 0 & 0 \\
\hline South Africa & 1 & 0.0119 & 1 & 0.758 & 0 & 0 & 0 \\
\hline Malaysia & 5 & 0.0595 & 1 & 0.758 & 0 & 0 & 0 \\
\hline Peoples Rep. China & 5329 & 63.4 & 1 & 0.758 & 0 & 0 & 0 \\
\hline Colombia & 1 & 0.0119 & 0 & 0 & 0 & 0 & - \\
\hline Finland & 1 & 0.0119 & 0 & 0 & 0 & 0 & - \\
\hline Kuwait & 1 & 0.0119 & 0 & 0 & 0 & 0 & - \\
\hline Macao & 1 & 0.0119 & 0 & 0 & 0 & 0 & - \\
\hline New Zealand & 1 & 0.0119 & 0 & 0 & 0 & 0 & - \\
\hline Republic of Ireland & 1 & 0.0119 & 0 & 0 & 0 & 0 & - \\
\hline Romania & 1 & 0.0119 & 0 & 0 & 0 & 0 & - \\
\hline Russian Federation & 1 & 0.0119 & 0 & 0 & 0 & 0 & - \\
\hline Brazil & 2 & 0.0238 & 0 & 0 & 0 & 0 & - \\
\hline Indonesia & 2 & 0.0238 & 0 & 0 & 0 & 0 & - \\
\hline Republic of Korea & 3 & 0.0357 & 0 & 0 & 0 & 0 & - \\
\hline Sweden & 3 & 0.0357 & 0 & 0 & 0 & 0 & - \\
\hline Italy & 9 & 0.107 & 0 & 0 & 0 & 0 & - \\
\hline Mongolia & 9 & 0.107 & 0 & 0 & 0 & 0 & - \\
\hline Philippines & 12 & 0.143 & 0 & 0 & 0 & 0 & - \\
\hline
\end{tabular}

Cases: Cumulative number of cases from 1 Nov 2002 to 6 June 2003 WHO Report (http://www.who.int/csr/sars/country/2003_06_06/en/)

\%Cases: percentage of cumulative number of cases, $\mathrm{P}$ : publications, $\% \mathrm{P}$ : percentage of publications,

$\mathrm{C}$ : citations, $\% \mathrm{C}$ : percentage of citations, $\mathrm{ACI}$ : actual citation impact 
Similar to the finding of a study on drug and alcohol journals, ${ }^{6}$ the quantity of SARSrelated articles were found to be low. That a high percentage share of news item was found might be a faster way of communication. As shown in Table 1, 256 documents were published in 64 SCI journals, with 61\% Northern American journals, $20 \%$ in European journals, 5\% in Asian journals and 3\% with no records in JCR of 2002. Four journals had impact factors higher than 20, 4 journals impact factors between 10 and 20, 4 between 5 and 10, 24 between 1 and 5, and 26 below 1 . Fifty-seven percent of the documents was published in journals with impact factors higher than 5 . The US dominated the journal countries followed distantly by the UK. Four languages were used for all SCI publications. Ninety-eight percent of total journals was published in English. Only 3 journals published in German, 2 in Spanish, and 1 in French.

In analyzing 132 documents with recorded addresses. We found that the US dominated the production by $30 \%$ of total share followed closely by Hong Kong with $24 \%$. Out of 38 document-producing countries, Belgium, Mexico, the Netherlands, Norway, Saudi Arabia, and Senegal did not report any SARS cases (Table 2). Out of 32 countries with SARS cases, $47 \%$ of them had no SCI publications. Surprisingly, China with most cases had only one SCI publication. Moreover, $24 \%$ of documents was published by Hong Kong where 1,750 cases have been reported. Sixty-three percent of publication was published by the mainstream countries such as the US, the UK, Canada, Germany, and Switzerland where only 302 cases have been reported totally.

Domination in publication was not surprising from mainstream countries since this pattern has occurred in most scientific fields. ${ }^{7,8}$ High production in countries with many cases would be due to active research of the disease, mainly on identification, diagnosis, and treatment. Contra wise mainstream countries would focus on controlling the disease and developing possible drugs and vaccines. The number of SARS cases did not affect the SCI publication output. However, countries with SARS cases, especially China, may have published in non-SCI journals that were not included in this study. All documents in this study were published in English. Thus, scientists in non-English speaking countries may have disadvantages in publishing in SCI journals since English is lingua franca of science. ${ }^{9,10}$ In a short period of time, English may not be the choice of communication language for those scientists who are not native speakers. Publishing was from Europe and Asia besides two Northern American countries. In our study, we found that only $17 \%$ of SARS-related papers were internationally collaborated. This finding is unusual since international collaboration is essential in modern science. ${ }^{11}$

Although citation by other authors was affected significantly by visibility, ${ }^{12}$ the citation frequency of SARS-related articles was considered to be high. Papers published from 11 countries had been cited in the short period after its appearance in print published. The country with the highest ACI value of 4.54 was the Netherlands. Except the US and the UK, all other countries have ACI higher than 1. The finding that low ACI values of these two countries was surprising because that both they had not had 
many reported SARS cases. In the ACI ranking, number of SARS cases has affected citation pattern. Hong Kong, where had the serious SARS outbreak and the sequencing of corona virus been completed, has the most impact to this field. Further analysis show that there is no evidence of association between number of national SARS cases and article production (Pearson $r=0.130, p$ value $=0.437$ ), national citations received (Pearson $r=0.248, p$ value $=0.134$ ), and national citation impact (Pearson $r=-0.046$, $p$ value $=0.835)$.

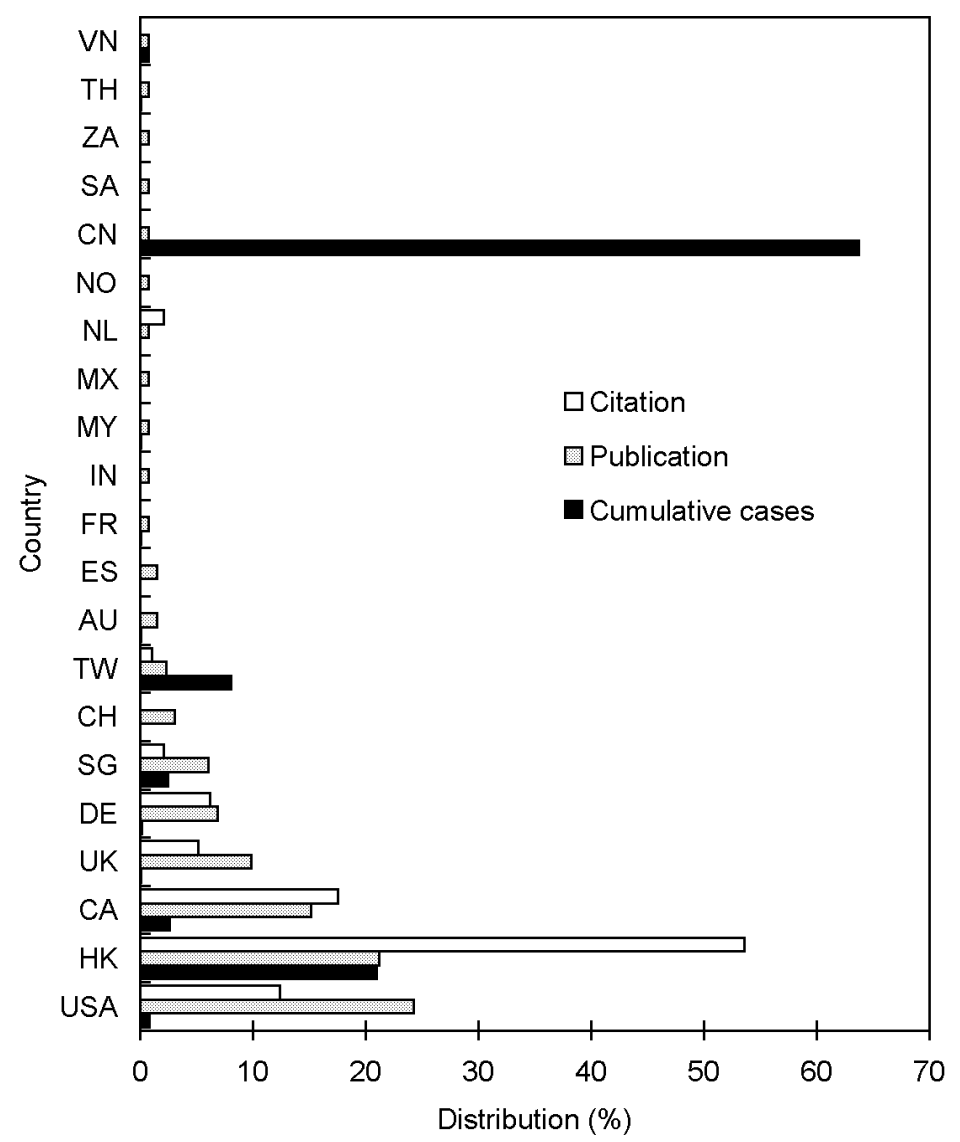

Figure 1. SARS cases, citation and publication distribution of reprint address

VN: Vietnam, TH: Thailand, ZA: South Africa, SA: Saudi Arabia, CN: Peoples Republic of China, NO: Norway, NL: Netherlands, MX: Mexico, MY: Malaysia, IN: India, FR: France, ES: Spain, AU: Australia, TW: Taiwan, CH: Switzerland, SG: Singapore, DE: Germany, UK: United Kingdom, CA: Canada, HK: Hong Kong, USA: United States 
In our study, we found that $48 \%$ of publications have no recorded reprint addresses. The sum of 21 countries was counted for the remaining ones distributed 9 in Asia, 7 in Europe, 2 in Northern America, and 1 in Africa, Central America, and Australia. Countries with reprint addresses showed similar publication and citation patterns as the origin of countries. The high percentage of documents that appeared without reprint addresses may be due to the low production of articles because other document types may not include them. The US dominated the number of publications and Hong Kong that of citation (Figure 1). Mainstream countries, the US, Canada, the UK, and Germany, published 81 (61\%) papers. The reprint address often represents the location when the research was done. Therefore, the results of this study indicate that most SARS research was done in the US, but that 10 papers had reprint address at the Chinese University at Hong Kong, 9 at University of Hong Kong, 7 at Center of Disease Control at Atlanta, 4 at WHO at Switzerland and Prince Wales Hospital in Hong Kong. Therefore, Hong Kong ranked the top for reprint address production.

\section{Conclusion}

SARS is not only a recent emerged disease, but also a new research topic. The SARS publication pattern in the first few months of its outbreak suggests immediate citation, low collaboration rate, and English and mainstream country domination in production, may be the features of this new topic which sets foot for future patterns. The results from this study showed no associations of research indexes with the number of cases. Although the major SARS outbreaks occurred in Asia, the high percentage of involvement from mainstream countries, suggests that SARS epidemic is no longer just a national affair of any single country but a disease that everyone should be aware.

\section{Reference}

1. R. M. KRAUSE, The origin of plagues - old and new. Science, 257 (1992) 1073-1078.

2. F. FLECK, Carlo Urbani - World Health Organization official who raised the alarm over severe acute respiratory syndrome - Obituary. British Medical Journal, 326 (2003) 825.

3. Cumulative number of cases from 1 Nov 2002 to 6 June 2003 WHO Report. Available at: http://www.who.int/csr/sars/country/2003_06_06/en/ Accessed July 19, 2003.

4. O. Persson, G. Melin, R. DAnell, A. Kaloudis, Research collaboration at Nordic universities. Scientometrics, 39 (1997) 209-223.

5. E. GARFIELD, Citation indexing for studying science. Nature, 227 (1970) 669-671.

6. M. O. HowARD, D. A. HowARD, Citation analysis of 541 articles published in drug and alcohol journals - 1984-1988. Journal of Studies on Alcohol, 53 (1992) 427-434. 
7. A. M. Brambrink, D. Ehrler, W. F. Dick, Publications on paediatric anaesthesia: A quantitative analysis of publication activity and international recognition. British Journal of Anaesthesia, 85 (2000) $556-562$.

8. G. S. Mela, M. A. Cimmino, D. Ugolini, Impact assessment of oncology research in the European Union, European Journal of Cancer, 35 (1999) 1182-1186.

9. E. Garfield, A. Welljams-Dorof, The microbiology literature: languages of publication and their relative citation impact. FEMS Microbiology Letters, 100 (1992) 33-37.

10. P. INGWERSEN, The international visibility and citation impact of Scandinavian research articles in selected social science fields, the decay of a myth. Scientometrics, 49 (2000) 39-61.

11. E. E. VogeL, Impact factor and international collaboration in Chilean physics: 1987-1994. Scientometrics, 38 (1996) 253-263.

12. A. W. JONES, Impact factors of forensic science and toxicology journals: what do the numbers really mean? Forensic Science International, 133 (2003) 1-8. 